\title{
Rhodoliths: Can Its Importance on a Large Scale Be Promoted by a Microscale and Invisible Phenomenon?
}

\author{
Renato Crespo Pereira ${ }^{1,2 *}$ and Ricardo da Gama Bahia ${ }^{2}$ \\ ${ }^{1}$ Marine Biology Department, Biology Institute, Federal Fluminense University, Niterói, Brazil, ${ }^{2}$ Botanical Garden Research \\ Institute of Rio de Janeiro, Rio de Janeiro, Brazil
}

Keywords: marine chemical ecology, chemical signal, chemical cue, benthic ecology, chemical mediation, epithallus sloughing, antifouling

\section{INTRODUCTION}

Rhodolith beds are widely distributed worldwide, from the tropics to the poles, and from the lowermost intertidal zone to depths over $200 \mathrm{~m}$ (Foster, 2001), and they are among the largest macrophyte-dominated benthic communities in the world, along with kelp beds, seagrass meadows, and coral reefs (Foster, 2001).

Rhodolith beds have been found throughout the world's oceans, but exhibiting a highly discontinuous global distribution, but larger concentrations of them are recorded off Southern Japan, Western Australia and the Gulf of California, as well as in the Mediterranean and along

\section{OPEN ACCESS}

Edited by:

Xosé Anxelu G. Morán,

King Abdullah University of Science and Technology, Saudi Arabia

Reviewed by: Francisco Arenas, University of Porto, Portugal

*Correspondence: Renato Crespo Pereira rcrespo@id.uff.br

Specialty section: This article was submitted to Marine Ecosystem Ecology, a section of the journal Frontiers in Marine Science

Received: 17 November 2020 Accepted: 26 January 2021 Published: 01 March 2021

Citation:

Pereira RC and da Gama Bahia $R$ (2021) Rhodoliths: Can Its Importance on a Large Scale Be Promoted by a

Microscale and Invisible Phenomenon?

Front. Mar. Sci. 8:630517.

doi: 10.3389/fmars.2021.630517
Norway, Ireland, Scotland, northeastern Canada, the Eastern Caribbean and Brazil (Foster, 2001). The world's largest beds occur in Abrolhos Shelf (Brazil)-SW Atlantic, which occupies $20.902 \mathrm{Km}^{2}$ (Amado-Filho et al., 2012), a geographic area comparable to that estimated for Caribbean coral reefs $\left(21.600 \mathrm{Km}^{2}\right)$ and the Great Barrier Reef $\left(20.055 \mathrm{Km}^{2}\right)$ (Vecsei, 2004).

There is an ongoing scientific interest in rhodolith beds (Riosmena-Rodríguez et al., 2017), mainly because they: (1) provide habitat to a high biodiversity of seaweeds, invertebrates and fish, also including some endemic, rare or commercially important species; (2) serve as recruitment areas or refuges for several marine organisms; (3) are sources of calcium carbonate for a wide variety of human application; (4) are sensitive to climate change and ocean acidification and (5) serve as paleoenvironmental indicators of past oceanic conditions. The diversity of organisms living on rhodoliths has been attributed to the provision of hard attachment surfaces on what would otherwise be a soft bottom (Foster et al., 2007).

Today, rhodoliths are seen as marine biodiversity hotspots, acting as seedbanks, temporary reservoirs for life history stages of ecologically important eukaryotic microalgae and macroalgae, or as refugia for ecosystem resilience following environmental stress (Fredericq et al., 2019).

\section{RHODOLITHS AS FOUNDATION SPECIES}

Since the beginning of the 20th century, rhodoliths are recognized as foundation species, because they house a great diversity of organisms (Weber-Van Bosse and Foslie, 1904) (Figure 1A). Since then, several further studies have reiterated this more than secular proposition, from the finding over 300 species of algae and invertebrates in rhodolith beds in the Gulf of California (Steller et al., 2003), more than 450 species in the Iberian Peninsula (Bordehore et al., 2003), 244 animals and 87 algal taxa recorded in Maltese Islands, Mediterranean (Sciberras et al., 2009), and 26 families of polychaete worms in the Southern Brazilian coast (Berlandi et al., 2012); including commercial species such as clams and scallops (Kamenos et al., 2004). Many species, including some cnidarians, echinoderms and 
chitons, appear to be rhodolith-specific (Steller et al., 2003).

Foundation species are capable of define ecosystems, control the biological diversity, and modulate critical ecosystem processes (Ellison, 2019), all predictable ecological roles to be performed by rhodolith beds.

\section{WOULD CHEMICAL SIGNALING BE A STRUCTURING COMPONENT OF RHODOLITH BEDS?}

For more than 50 years seaweeds have been known as sources of secondary metabolites acting as positive chemical cues or signals for settlement or/or metamorphosis inducers (Crisp, 1974), encompassing a large number of planktonic life stages of a broad variety of benthic marine organisms, from bacteria to marine invertebrates (Hadfield and Paul, 2001); but rhodolithforming coralline algae have been the most prolific in the production of these chemicals. For example, chemicals from species of the known components of rhodoliths, species of Lithothaminion, Phymatolithon and Sporolithon, induce settlement and/or metamorphosis of some invertebrates, such as the serpulid worm Spirorbis rupestris (Gee, 1965), the chiton Tonicella lineata (Barnes and Gonor, 1973), the sea urchin Strongylocentrotus droebachiensis (Pearce and Scheibling, 1990), and also species of high economic interest such as species of the abalone Haliotis (Daume et al., 1999). Chemicals from the rhodolith-forming species Lithophyllum yessoense exhibit ecological role as multiple allelopathic against settlement and germination of fleshy green, brown, and red marine macroalgae (Kim et al., 2004). Other chemical-types produced by rhodolith-forming coralline algae need more attention, such as dimethylsulfoniopropionate (DMSP) that have been identified as cryoprotectant, antioxidant, and possible defensive compounds against grazer (McCoy and Kamenos, 2015) and was found at high concentrations in the temperate rodolith-forming species Lithothamnion glaciale and Phymatolithon calcareum (Kamenos et al., 2008).

Species-specific colonization cues may also, or instead, be associated with chemicals produced by microbiome/biofilm growing on the rhodolith-forming coralline algal surface (Huggett et al., 2006). Although more recent evidence has revealed that biofilm on CCA did not promoted settlement response in larvae of 11 coral species from Australia, Guam, Singapore and Japan (Tebben et al., 2015). This conflicting theme or even the possible interaction between secondary metabolites and microbiomes needs to be targets of greater attention due to the importance that may represent as micro-scale or also invisible phenomenon relevant for the structuring of rhodolith beds.

An additional recognized ecological role from macroalgal chemicals is the antifouling activity proportionate by formation of reactive oxygen species (ROS), usually denominated "oxidative burst" (Potin, 2008). We do not know evidence of this phenomenon in rhodolith-forming coralline algae, but this control on fouling may be a structuring mechanism exerted by fleshy species of green, brown, and red macroalgae associated with rhodolith beds worldwide. However, the only example we known is the production of ROS by geniculated Corallina officinalis after increases in temperature (Latham, 2008) and induction by UV-radiation ( $\mathrm{Li}$ et al., 2010), which may be an indication that other calcareous algae, including rhodolithforming, may also produce them.

Epibionts are known for the adverse or harmful effects they exert on basibionts, constituting selective pressure for the evolution of all defensive/stimulating mechanisms in marine macroalgae (Da Gama et al., 2014). An another invisible mechanism to control epibionts is the epithallus sloughing anti-fouling defense employed mainly by calcareous macroalgal species, such as rodolith-forming species of Clathromorphum (Pueschel and Miller, 1996), Hidrolithon (Keats et al., 1997), Lithothamnion (Masaki et al., 1984), Neogoniolithon (Masaki et al., 1984, Keats et al., 1997, Littler and Littler, 1999), Spongites (Keats et al., 1993), Sporolithon (Keats et al., 1997), and Phymattolithon (Johnson and Mann, 1986). However, there is still scarce evidence of the ecological significance of this mechanism under natural conditions, since most of the studies were performed under laboratory conditions (Da Gama et al., 2014); but for field evidences, see Johnson and Mann (1986) and Keats et al. (1997).

In addition to rhodolith-forming algae, bacteria (Dobretsov et al., 2009) and several other coralline (Kim et al., 2004), and fleshy macroalgae (Longo and Hay, 2017) as soon as marine invertebrates, such as sponges (e.g., Pawlik, 2011), gorgonians (e.g., Ribeiro et al., 2017), corals (Changyun et al., 2008), bryozoans (Sharp et al., 2007), and other benthic organisms that live in rhodolith beds, can also produce diverse substances capable of generating structuring-effects in these environments.

These examples mentioned above are isolated or nonintegrated sources about the importance of chemical signals and cues as structuring components for the rhodolith beds. However, they express the dimension that chemical signaling or antifouling mechanisms can have for the ecology of rhodolith beds.

Despite the lack of these integrated ecological studies, there is evidences that these chemical signals can be applied to efforts of coral reef restoration (Pollock et al., 2017). The structuring potential of chemical mediation in rhodolith beds is also of enormous interest in the current context of global changes (McCoy and Kamenos, 2015). For example, a minimal increase in temperature causes a change in the structure of the microbial community on the surface of Neogoniolithon fosliei and the ability to induce coral larvae metamorphosis (Webster et al., 2011). In this same scenario of global changes, an increase in the concentration of $\mathrm{CO}_{2}$ promoted a change in the recruitment of the Acropora millepora coral over encrusting calcareous algae (Doropoulos et al., 2012). In a relatively recent review, several aspects related to the ecology and physiology of calcareous algae were brought together in order to understand their responses to global climate change (McCoy and Kamenos, 2015). In view of the crucial importance of chemical signaling for the diversity of tropical and temperate marine communities, this review expresses a concern about the need to know the impacts of climate change on chemical signaling.

Marine chemical ecology studies are unequivocal in revealing the relevant ecological roles of secondary metabolites in inter- 
and intra-specific relationships among marine organisms and their strong and cascade effects on population structure, community organization, and ecosystem function (Hay, 2009). Secondary metabolites and other chemicals are true keystones, since through convergent evolution they inform phylogenetically diverse species (Ferrer and Zimmer, 2013), and also maintain marine biodiversity (Pereira et al., 2017).

In coral reefs, the chemically mediated ecological roles seem to have their greatest expression compared with other marine environments (Hay, 2009), encompassing actions such as defense against consumers and pathogens, interference in the evolution of feeding preferences and specialization in tri-trophic interactions, antifouling and allelopathy property, and cascade effects on population regulation and structuring community. Therefore, we believe that chemical mediations exhibit the same dimension and importance as structuring for rhodolith beds as well as for coral reefs. Although invisible, chemicals and epithallus sloughing from the rhodolith-forming coralline algae and associated bacteria, fleshy macroalgae and marine invertebrates seems to be a major venue by which is promoted and maintained the biodiversity of rhodoliths beds worldwide (Figure 1B). However, the presence and importance of chemical

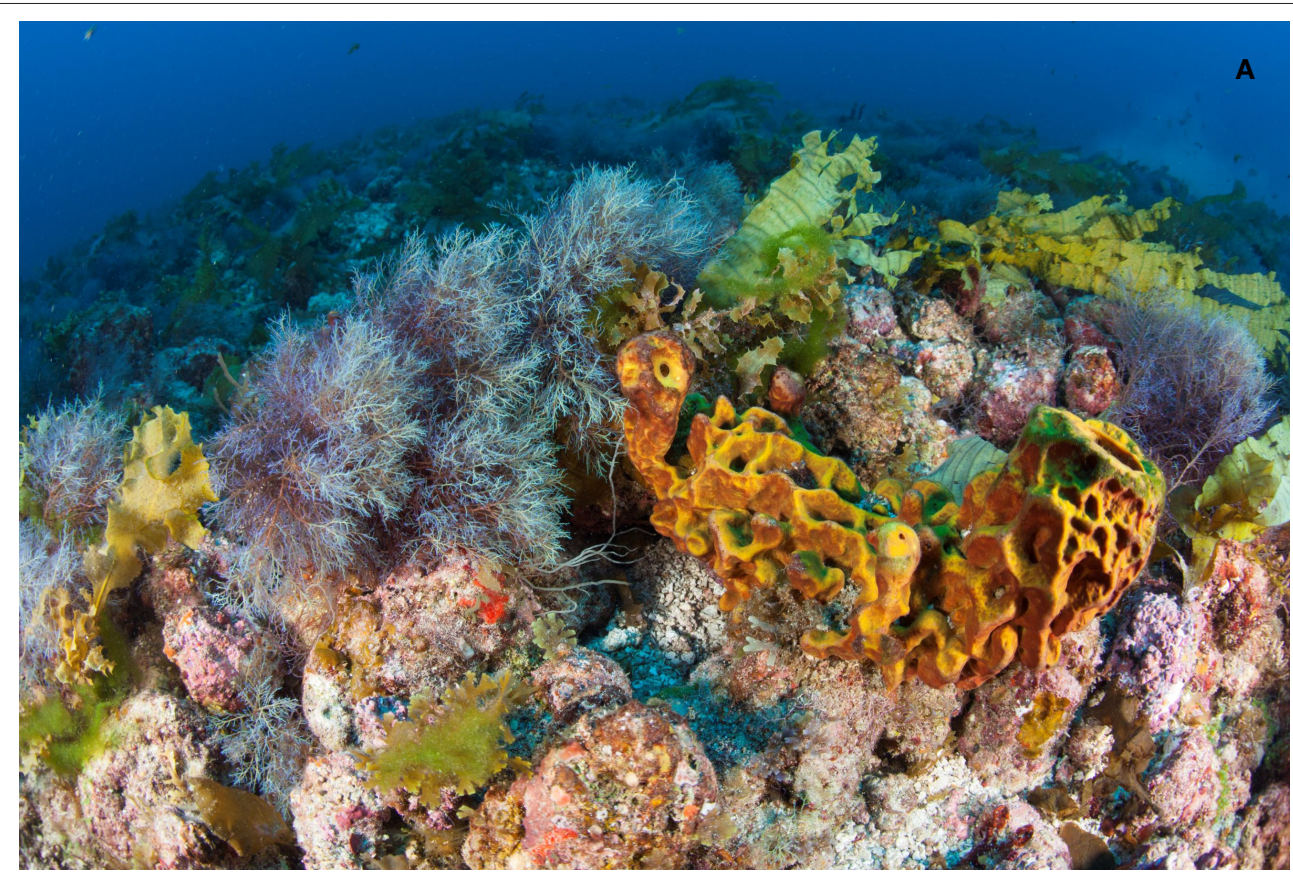

B

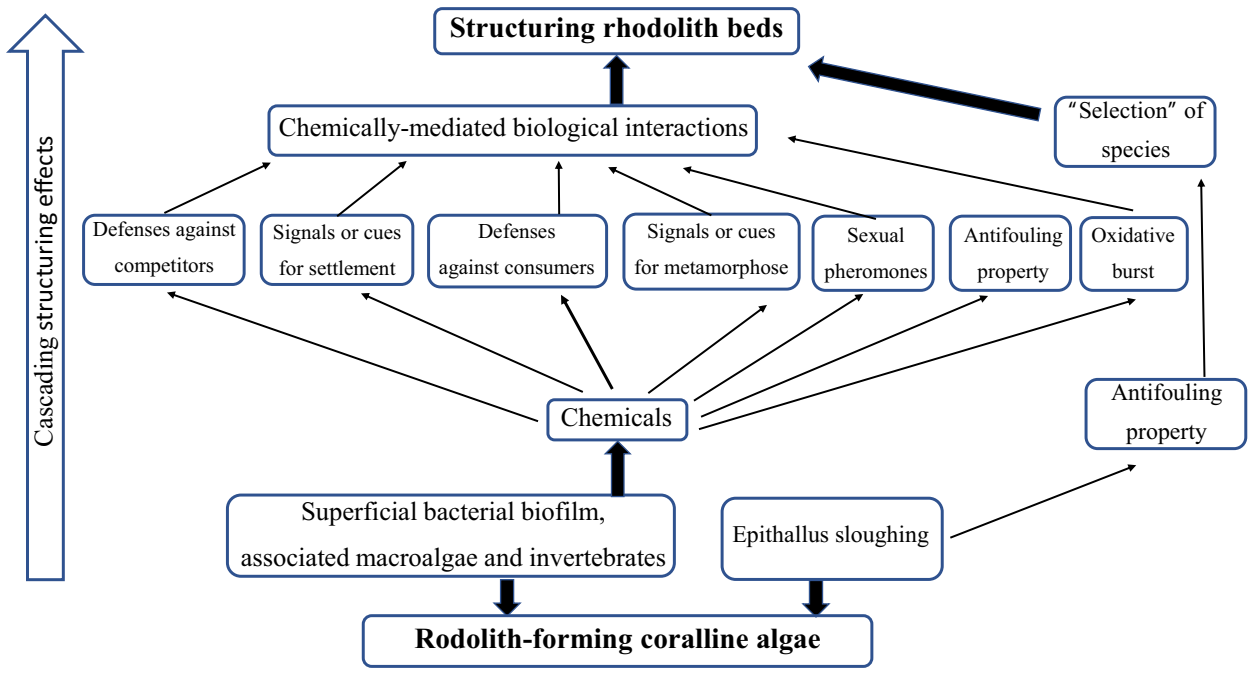

FIGURE 1 | (A) A diverse community of macroalgae and invertebrates inhabiting a rhodolith bed at the Abrolhos Bank, Brazil. Photo by Áthila Bertoncini/Rede Abrolhos. (B) Possible mediation among organisms in rhodolith beds that may be key for its community structuring. 
mediation in rhodolith beds are still overlooked and should be adequately recognized in future integrated studies.

\section{AUTHOR CONTRIBUTIONS}

All authors contributed to idea/conception the article and approved the submitted version.

\section{FUNDING}

This study was supported by Conselho Nacional de Desenvolvimento Cientifico e Tecnológico (CNPq,

\section{REFERENCES}

Amado-Filho, G. M., Moura, R. L., Bastos, A. C., Salgado, L. T., Sumida, P. Y., Guth, A. Z., et al. (2012). Rhodolith beds are major $\mathrm{CaCO}_{3}$ bio-factories in the tropical South West Atlantic. PLoS ONE 7:e35171. doi: 10.1371/journal.pone.0035171

Barnes, J. R., and Gonor,. J. J. (1973). The larval settling response of the lined chiton Tonicella lineata. Mar. Biol. 201, 259-264.

Berlandi, R. M., Figueiredo, M. A. O., and Paiva, P. C. (2012). Rhodolith morphology and the diversity of polychaetes off the southeastern Brazilian coast. J. Coast. Res. 28, 280-287. doi: 10.2112/11T-00002.1

Bordehore, C., Ramos-Esplá, A. A., and Riosmena-Rodríguez, R. (2003). Comparative study of two maërl beds with different otter trawling history, southeast Iberian Peninsula. Aquat. Conserv. 13, 43-54. doi: 10.1002/aqc.567

Changyun, W., Haiyana, L., Changluna, S., Yanan, W., Liang, K., and Huashia, G. (2008). Chemical defensive substances of soft corals and gorgonians. Acta Ecol. Sin. 28, 2320-2328. doi: 10.1016/S1872-2032(08)60048-7

Crisp, D. J. (1974). "Factors infuencing the settlement of marine invertebrate larvae," in Chemoreception in Marine Organisms, eds P. T. Grant and A.M. Mackie (NewYork, NY: AcademicPress), 177-185.

Da Gama, B. A. P., Plouguerné, E., and Pereira, R. C. (2014). The antifouling defence mechanisms of marine macroalgae. Adv. Bot. Res. 71, 413-440. doi: 10.1016/B978-0-12-408062-1.00014-7

Daume, S., Brand-Gardner, S., and Woelkerling, W. J. (1999). Settlement of abalone larvae (Haliotis laevigata Donovan) in response to non-geniculate coralline red algae (Corallinales, Rhodophyta). J. Exp. Mar. Biol. Ecol. 234, 125-143. doi: 10.1016/S0022-0981(98)00143-9

Dobretsov, D., Teplitski, M., and Paul, V. (2009). Mini-review: quorum sensing in the marine environment and its relationship to biofouling. Biofouling 25, 413-427. doi: 10.1080/08927010902853516

Doropoulos, C., Ward, S., Diaz-Pulido, G., Hoegh-Guldberg, O., and Mumby, P. J. (2012). Ocean acidification reduces coral recruitment by disrupting intimate larval-algal settlement interactions. Ecol. Lett. 15, 338-346. doi: 10.1111/j.1461-0248.2012.01 743.x

Ellison, A. M. (2019). Foundation species, non-trophic interactions, and the value of being common. iScience 13, 254-268. doi: 10.1016/j.isci.2019.0 2.020

Ferrer, R. P., and Zimmer, R. K. (2013). Molecules of keystone significance: crucial agents in ecology and resource management. Bioscience 63, 428-438. doi: 10.1525/bio.2013.63.6.5

Foster, M. S. (2001). Rhodoliths: between rocks and soft places. J. Phycol. 37, 659-667. doi: 10.1046/j.1529-8817.2001.00195.x

Foster, M. S., McConnico, L. M., Lundsten, L., Wadsworth, T., Kimball, T., Brooks, L. B., et al. (2007). Diversity and natural history of Lithothamnion muelleriSargassum horridum community in the Gulf of California. Cienc. Mar. 33, 367-384. doi: $10.7773 / \mathrm{cm} . v 33 i 4.1174$

Fredericq, S., Krayesky-Self, S., Sauvage, T., Richards, J., Kittle, R., Arakaki, N., et al. (2019). The critical importance of rhodoliths in the life cycle completion of both macro- and microalgae, and as holobionts for the
310464/2016-1) and the Fundação de Amparo à Pesquisa do Estado do Rio de Janeiro (Faperj E-26/202.689/2019).

\section{ACKNOWLEDGMENTS}

RP is supported by Conselho Nacional de Desenvolvimento Científico e Tecnológico (CNPq, 310464/2016-1), the Fundação de Amparo à Pesquisa do Estado do Rio de Janeiro (E26/202.689/2019). We thank Dr. Áthila Bertoncini, author of the Figure 1A used in this article. RP and RG thank CNPq for Research Productivity and Posdoctoral fellowships, respectively.

establishment and maintenance of marine biodiversity. Front. Mar. Sci. 5:502. doi: 10.3389/fmars.2018.00502

Gee, J. M. (1965). Chemical stimulation of settlement of larvae of Spirorbis rupestris (Serpulidae). Anim. Behav. 13, 181-186. doi: 10.1016/0003-3472(65)90090-4

Hadfield, M. G., and Paul, V. J. (2001). "Natural chemical cues for settlement and metamorphosis of marine-invertebrate larvae," in Marine Chemical Ecology, eds J. B. McClintock and B.J. Baler (Boca Raton, FL: CRC Press), 431-461.

Hay, M. E. (2009). Marine chemical ecology: chemical signals and cues structure marine populations, communities, and ecosystems. Ann. Rev. Mar. Sci. 1, 193-212. doi: 10.1146/annurev.marine.010908.163708

Huggett, M. J., Williamson, J. E., de Nys, R., Kjelleberg, S., and Steinberg, P. D. (2006). Larval settlement of the common Australian sea urchin Heliocidaris erythrogramma in response to bacteria from the surface of coralline algae. Oecologia 149, 604-619. doi: 10.1007/s00442-006-0470-8

Johnson, C. R., and Mann, K. H. (1986). The crustose coralline alga, Phymatolithon Foslie, inhibits the overgrowth of seaweeds without relying on herbivores. J. Exp. Mar. Biol. Ecol. 96, 127-146. doi: 10.1016/0022-0981(86)90238-8

Kamenos, N. A., Moore, G. P., and Hall-Spencer, J. M. (2004). Nurseryarea function of maërl grounds for juvenile queen scallops Aequipecten opercularis and other invertebrates. Mar. Ecol. Prog. Ser. 274, 183-189. doi: $10.3354 /$ meps 274183

Kamenos, N. A., Strong, S. C., Shenoy, D. M., Wilson, S. T., Hat- ton, A. D., and Moore, P. G. (2008). Red coralline algae as a source of marine biogenic dimethylsulphoniopropionate. Mar. Ecol. Prog. Ser. 372, 61-66. doi: $10.3354 /$ meps07687

Keats, D. W., Groener, A., and Chamberlain, Y. M. (1993). Cell sloughing in the littoral zone coralline alga, Spongites yendoi (Foslie) Chamberlain (Corallinales, Rhodophyta). Phycologia 32, 143-150. doi: 10.2216/i0031-8884-32-2-143.1

Keats, D. W., Knight, M. A., and Pueschel, C. M. (1997). Antifouling effects of epithallial shedding in three crustose coralline algae (Rhodopyhta, Corallinales) on a coral reef. J. Exp. Mar. Biol. Ecol. 213, 281-293. doi: 10.1016/S0022-0981(96)02771-2

Kim, J., Choi, J. S., Kang, S. E., Cho, J. Y., Jin, H. J., Chun, B. S., et al. (2004). Multiple allelopathic activity of the crustose coralline alga Lithophyllum yessoense against settlement and germination of seaweed spores. J. Appl. Phycol. 16, 175-179. doi: 10.1023/B:JAPH.0000048497.62774.38

Latham, H. (2008). Temperature stress-induced bleaching of the coralline alga Corallina officinalis: a role for the enzyme bromoperoxidase. Biosci. Horiz. 1, 104-113. doi: 10.1093/biohorizons/hzn016

Li, L., Zhao, J., and Tang, X. (2010). Ultraviolet irradiation induced oxidative stress and response of antioxidant system in an intertidal macroalgae Corallina officinalis L. J. Environ. Sci. 22, 716-722. doi: 10.1016/S1001-0742(09)6 0168-6

Littler, M. M., and Littler, D. S. (1999). Epithallus sloughing: a self-cleaning mechanism for coralline algae. Coral Reefs 18:204. doi: 10.1007/s003380050182

Longo, G. O., and Hay, M. E. (2017). Seaweed allelopathy to corals: are active compounds on, or in, seaweeds? Coral Reefs 36, 247-253. doi: 10.1007/s00338-016-1526-9

Masaki, T., Fujita, D., and Hagen, N. (1984). The surface ultrastructure and epithallium shed- ding of crustose coralline algae in an "isoyake" 
area of southwestern Hokkaido, Japan. Hydrobiologia 116/117, 218-223. doi: $10.1007 / \mathrm{BF} 00027669$

McCoy, S. J., and Kamenos, N. A. (2015). Coralline algae (Rhodophyta) in a changing world: integrating ecological, physiological, and geochemical responses to global change. J. Phycol. 51, 6-24. doi: 10.1111/jpy.12262

Pawlik, J. R. (2011). The chemical ecology of sponges on Caribbean reefs: natural products shape natural systems. BioScience 81, 888-898. doi: 10.1525/bio.2011.61.11.8

Pearce, C. M., and Scheibling, R. E. (1990). Induction of metamorphosis of larvae of the green sea-urchin, Strongylocentrotus droebachiensis, by coralline red algae. Biol. Bull. 179, 304-311. doi: 10.2307/1542322

Pereira, R. C., Da Gama, B. A. P., and Sudatti, D. B. (2017). "The role of chemically defended seaweeds as biodiversity sources," in Marine Macrophytes as Foundation Species, ed E. Olafsson (Boca Raton, FL: CRC Press), 26-42.

Pollock, F. J., Katz, S. M., van de Water, J. A. J. M., Davies, S. W., Hein, M., Torda, G., et al. (2017). Coral larvae for restoration and research: a large-scale method for rearing Acropora millepora larvae, inducing settlement, and establishing symbiosis. PeerJ. 5:e3732. doi: 10.7717/peeri.3732

Potin, P. (2008). "Oxidative burst and related responses in biotic interactions of algae," in Algal Chemical Ecology, ed C. D. Amsler (Berlin: Springer-Verlag), 445-271.

Pueschel, C. M., and Miller, T. J. (1996). Reconsidering prey specializations in an algal-limpet grazing mutualism: epithallial cell development in Clathromorphum circumscriptum (Rhodophyta, Corallinales). J. Phycol. 32, 28-36. doi: 10.1111/j.0022-3646.1996.00028.x

Ribeiro, F. V., Da Gama, B. A. P., and Pereira, R. C. (2017). Structuring effects of chemicals from the sea fan Phyllogorgia dilatata on benthic communities. PeerJ. 5:e3186. doi: 10.7717/peerj.3186

Riosmena-Rodríguez, R., Nelson, W., and Aguirre, J. (eds). (2017). Rhodolith/Maerrl Beds: A Global Perspective. Cham: Springer International Publishing.

Sciberras, M., Rizzo, M., Mifsud, J. R., Camilleri, K., Borg, J. A., Lanfranco, E. P., et al. (2009). Habitat structure and biological characteristics of a
maÃ $\ll \mathrm{rl}$ bed off the northeastern coast of the Maltese Islands (central Mediterranean). Mar. Biodivers. 39, 251-264. doi: 10.1007/s12526-00 9-0017-4

Sharp, J. H., Winson, M. K., and Porter, J. S. (2007). Bryozoan metabolites: an ecological perspective. Nat. Prod. Rep. 24, 659-673. doi: 10.1039/b617546e

Steller, D. L., Riosmena-Rodríguez, R., Foster, M. S., and Roberts, C. A. (2003). Rhodolith bed diversity in the Gulf of California: the importance of rhodolith structure and consequences of disturbance. Aquat. Conserv. 13(Suppl. 1), S5-S20. doi: 10.1002/aqc.564

Tebben, J., Motti, C. A., Siboni, N., Tapiolas, D. M., Negri, A. P., Schupp, P. J., et al. (2015). Chemical mediation of coral larval settlement by crustose coralline algae. Sci. Rep. 5:10803. doi: 10.1038/srep10803

Vecsei, A. (2004). Carbonate production on isolated banks since $20 \mathrm{k}$.a.BP: climatic implications. Palaeogeogr. Palaeoclimatol. Palaeoecol. 214, 3-10. doi: 10.1016/S0031-0182(04)00319-0

Weber-Van Bosse, A., and Foslie, M. (1904). The corallinaceae of the siboga expedition. Siboga Expeditie 61, 1-110. doi: 10.5962/bhl.title.157055

Webster, N. S., Soo, R., Cobb, R., and Negri, A. P. (2011). Elevated seawater temperature causes a microbial shift on crustose coralline algae with implications for the recruitment of coral larvae. ISME J. 5, 759-770. doi: $10.1038 /$ ismej.2010.152

Conflict of Interest: The authors declare that the research was conducted in the absence of any commercial or financial relationships that could be construed as a potential conflict of interest.

Copyright (๑) 2021 Pereira and da Gama Bahia. This is an open-access article distributed under the terms of the Creative Commons Attribution License (CC BY). The use, distribution or reproduction in other forums is permitted, provided the original author(s) and the copyright owner(s) are credited and that the original publication in this journal is cited, in accordance with accepted academic practice. No use, distribution or reproduction is permitted which does not comply with these terms. 